https://doi.org/10.15407/scin16.01.045

GRINYOV, B.V., CHERGINETS, V.L., REBROVA, T.P., PONOMARENKO, T.V., VARICH, A.G. , and REBROV, A.L. Institute for Scintillation Materials, the NAS of Ukraine, 60, Nauky Ave., Kharkiv, 61072, Ukraine, +380 $573410150,+380573404474$, v_cherginets@ukr.net

\title{
TECHNOLOGY FOR DEEP PURIFICATION OF CESIUM IODIDE SINGLE CRYSTAL PRODUCTION WASTES FROM HEAVY METALS
}

Introduction. The production of CsI-based scintillation crystals results in accumulation of wastes formed during the crystal growth and as a result of the mechanical treatment. Therefore, thorough purification from heavy metals is the main condition of CsI recycling for the further application in obtaining the different activated single crystals.

Problem Statement. Thallium is one of the main admixtures in the wastes of CsI-based crystal production because it is used as an activating admixture for the of CsI:Tl crystals. Since Tl is referred to heavy metals which are hardly removable from the wastes of CsI crystal production the development of the purification technology of technogenic CsI solution from admixtures of heavy metals is necessary.

Purpose. The development of technology providing purification of the wastes of CsI-based crystal production to the level required by national normative documentation for extra pure CSI.

Materials and Methods. Materials: the liquid wastes of CsI-based crystal production (the CsI solution), activated carbon, metallic magnesium, barium hydroxide, cesium carbonate. Methods: the treatment of mixture of the heated CsI solution with the purifier by stirring, the multiple filtering of the heated CsI through the cartridge filters filled with purifying reagents.

Results. The method for treatment of technogenic CSI solution with magnesium at heating and stirring proved to be successful under laboratory conditions, however, attempts to level it up for the industrial scale failed. Multiple filtering of the heated reagent mixture through the cartridge filters filled with purifying reagents proved to be better and led to successful industrial examinations. It gives the possibility to obtain the extra pure product, CSI, meeting requirements of TU U 24.13.31331736-002-2004 for cesium iodide.

Conclusions. A new technology for deep purifying the wastes of CsI-based crystal production from heavy metals including thallium has been developed.

Keywords: cesium iodide, technogenic solution, purification, heavy metals, and magnesium.

The manufacture (growth and further mechanical processing) of optical halide single crystals based on water-soluble salts of alkali metals is inevitably accompanied with the accumulation of considerable wastes in different forms: fusion cakes from the growth cru-

Citation: Grinyov, B.V., Cherginets, V.L., Rebrova, T.P., Ponomarenko, N.V., Varich, A.G., and Rebrov, A.L. Technology for deep purification of cesium iodide single crystal production wastes from heavy metals. Sci. innov. 2020. V. 16, no. 1. P. 45-53. https://doi.org/10.15407/scine16.01.045 
cibles, the cuttings of the single crystals, solutions formed during the washing of growth equipment etc. The fraction of such wastes can exceed a half of the mass of the grown single crystals. Therefore, the manufacturers of these crystals are extremely interested in the reprocessing of the said wastes into charge of high chemical purity for closing the production cycle and, hence, for the increase of the production efficiency.

All the above-said concerns the manufacturing of CsI-based single crystals, which are widely used in optics as windows for IR radiation (undoped cesium iodide) and in the scintillation techniques as detectors of ionizing irradiation (CsI, CsI:Na and CsI:Tl single crystals).

Practically, all the wastes are not kept separately and they are contaminated by $\mathrm{Na}$, $\mathrm{Tl}$ (activating dopants) and heavy metals from constructional materials used for the growth and technological water. Therefore, it is necessary to develop a technology providing deep purification of CsI wastes from activating dopants and heavy metal admixtures to meet the extra pure chemical grade required for the further growth of Cs-based single crystals.

The present-day technology of CsI-based single crystal waste reprocessing provides the 3 -fold mass crystallization which is performed after the solution filtration through the activated carbon and the chemical purification of filtered solution from sulfates and heavy and alkaline earth metal impurities by the sequential treatment of the technogenic solutions with barium hydroxide and cesium carbonate.

However, the chemical treatment does not provide the removal of thallium compounds which somewhat resemble the similar salts of alkali metals (e.g., hydroxide and carbonate of thallium are highly soluble in water [1]) and the solution directed to the mass crystallization contains $\mathrm{Tl}^{+}$ and $\mathrm{Na}^{+}$ions simultaneously. The behavior of these admixtures during the crystallization is quite different: the sodium admixture is removed from the product in the mother water, whereas thallium is collected in the solid cesium iodide [2]. So, the CsI salt obtained by such a manner can be used only for the growth of CsI:Tl single crystals where sodium admixture is not harmful. On the contrary, the addition of mere amounts of $\mathrm{NaI}$ (ca. 1 mas. \%) facilitates growth of large-sized CsI:Tl single crystals. The said charge is not appropriate for the growth of CsI:Na crystals. To extend the use of CsI obtained from the wastes it is necessary to provide more thorough purification of the salt from heavy metal admixtures including $\mathrm{Tl}$.

The purpose of this research is to develop technological principles of purification of cesium iodide technogenic solutions from admixtures of heavy metals including thallium.

The radical solution of the problem of cesium iodide salt purification from traces of heavy metals consists in the treatment of the technogenic solution with magnesium as one of the most active metals which, nevertheless, practically does not react with water at room temperature and, therefore, it can be used for the treatment of aqueous solutions. From the viewpoint of electrochemistry magnesium is placed far to the left in the electrochemical voltage series of metals comparing with heavy metals: the difference exceeds $1 \mathrm{~V}$ for all the heavy metals and it is ca. $2 \mathrm{~V}$ for thallium [1]. It means that all the heavy metals existing in the aqueous solution in ionic form should be quantitatively displaced (precipitated) by metallic magnesium.

The preliminary experiments were performed under laboratory conditions. Methods which have given the positive results were checked at the industrial level. The solution of cesium iodide obtained after the separation from TlI precipitate and the filtration through activated carbon was used for the experiments (the initial CsI solution).

There were two kinds of laboratory experiments.

The first one (routine L1) consisted in the heating of $500 \mathrm{ml}$ of the initial CsI solution with the suspended magnesium powder $(0.5 \mathrm{~g})$ in a laboratory glass with the volume of $1000 \mathrm{ml}$ to $70-80{ }^{\circ} \mathrm{C}$ 


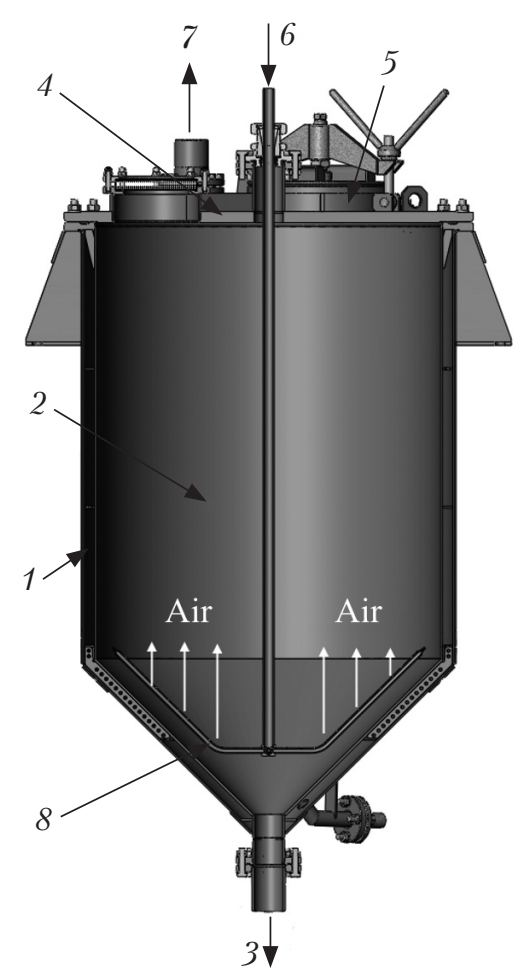

Fig. 1. The cross-sectional view of the heat-exchange (crystallization) apparatus exploited in pilot production of ISMA (titanium): 1 - heat-exchanging jacket; 2 - working volume; 3 - flange with connection (bleeding to suction filter); 4 - top; 5 - hatch for entering solid reagents; 6 - air inlet; 7 - vacuum outlet; 8 - air dispenser

at the stirring (120 rpm) during 4 hours. Then the solution was cooled to room temperature and kept for 20-24 hours.

The second way (routine L2) consisted in the passing of $1000 \mathrm{ml}$ of the initial CsI solution heated to $60{ }^{\circ} \mathrm{C}$ through the sorption column filled with magnesium with the rate of $100 \mathrm{ml}$ per hour, the height of $\mathrm{Mg}$ layer was ca. $25 \mathrm{~cm}$. The passing through $\mathrm{Mg}$ was performed several times up to achieving necessary degree of the CsI solution purification from $\mathrm{Tl}$.

The efficiency of the routines was checked by determination of magnesium content and thallium after the finishing of the treatment.

Experiments at the industrial scale were performed in standard titanium heat-exchange apparatus of volume of 2501 exploited in pilot pro- duction of Institute for Scintillation Materials of National Academy of Sciences of Ukraine (ISMA) (Fig.1). There were performed two kinds of experiments which were principally corresponding to the laboratory ones.

The first kind of the technological experiments (routine T1) consisted in the heating of 1001 of the initial CsI solution with the suspended magnesium powder $(50 \mathrm{~g})$ to $70-80{ }^{\circ} \mathrm{C}$ with the stirring by air supplied from the bottom of the reactor during 4 hours. Then the solution was cooled to room temperature and kept for 20-24 hours. The treated solution was filtered through the suction filter and then was passed to chemical treatment and the following 3 -fold mass crystallization.

The chemical treatment consisted in the addition of barium hydroxide to the solution heated to $60{ }^{\circ} \mathrm{C}$. This led to the removal of admixtures of sulfates, heavy metals and magnesium according to the following reactions:

$$
\begin{gathered}
\mathrm{Ba}(\mathrm{OH})_{2}+\mathrm{Cs}_{2} \mathrm{SO}_{4} \rightarrow \mathrm{BaSO}_{4} \downarrow+2 \mathrm{CsOH},(1) \\
\mathrm{MI}_{\mathrm{n}}+n \mathrm{CsOH} \rightarrow \mathrm{M}(\mathrm{OH})_{n} \downarrow+n \mathrm{CsI},
\end{gathered}
$$

where $\mathrm{M}$ was $\mathrm{Fe}^{2+}, \mathrm{Fe}^{3+}, \mathrm{Ni}^{2+}, \mathrm{Mn}^{2+}, \mathrm{Mg}^{2+}$ etc. The slightly soluble hydroxides were adsorbed by developed surface of $\mathrm{BaSO}_{4}$ precipitate.

Then the admixtures of the dissolved barium and alkaline earth metal compounds were removed by the addition of cesium carbonate to the solution of CsI heated to $60{ }^{\circ} \mathrm{C}$ :

$$
\mathrm{MI}_{2}+\mathrm{Cs}_{2} \mathrm{CO}_{3} \rightarrow \mathrm{MCO}_{3} \downarrow+2 \mathrm{CsI},
$$

where $\mathrm{M}=\mathrm{Ba}, \mathrm{Sr}$, $\mathrm{Ca}$.

The filtered solution had been evaporated at $85-90{ }^{\circ} \mathrm{C}$ under lowered pressure $(-0.9 \mathrm{~atm})$ until the crystals (crystalline film) appeared at the surface solution. The having been evaporated solution was cooled to room temperature, filtered through suction filter. The separated crystals were subjected to the crystallization from the saturated solution two times again.

The second kind of the experiments (routine T2) was fulfilled by such a manner. The initial 
CsI solution (185 l) was heated in the apparatus to $60-70{ }^{\circ} \mathrm{C}$ and pumped through two cartridge filters one of which was filled with magnesium and another was filled with activated carbon using a metering pump with the rate of $7-81$ per an hour. The common view of such a node of CsI purification is presented in Fig. 2.

After 5-fold repeating of this routine the solution was passed to the chemical treatment and the following 3 -fold mass crystallization.

The samples of CsI salts obtained after the experiments were analyzed to determine the content of admixtures of magnesium and the heavy metals.

The initial CsI solutions possessing $\mathrm{pH}$ within 10.2-10.6 was used for the experiments. This can be explained by the fact that there are no hard regulations that control the period of CsI wastes (solution or solid salt) storage and it can vary from several months to year or even more. Naturally, the wastes are subjected to the action of the air. The main process taking place under these conditions is the oxidation of CsI by atmospheric oxygen:

$$
2 \mathrm{CsI}+\frac{1}{2} \mathrm{O}_{2} \uparrow+\mathrm{H}_{2} \mathrm{O} \rightarrow 2 \mathrm{CsOH}+\mathrm{I}_{2}(\uparrow) .
$$

Iodine is evaporated from the solution which becomes more alkaline. This solution can further interact both with iodine:

$$
3 \mathrm{I}_{2}+6 \mathrm{CsOH} \rightarrow 5 \mathrm{CsI}+\mathrm{CsIO}_{3}+3 \mathrm{H}_{2} \mathrm{O}
$$

and with atmospheric carbon dioxide

$$
\mathrm{CO}_{2}+2 \mathrm{CsOH} \rightarrow \mathrm{Cs}_{2} \mathrm{CO}_{3}+\mathrm{H}_{2} \mathrm{O} \text {. }
$$

The latter reaction is predominant since the running of reaction (5) results in the considerable decrease of the solution alkalinity whereas the occurring of reaction (6) leads to slight alkalinity decrease and $\mathrm{pH}$ value within $10-11$ is typical for solutions of alkali metal carbonates of different concentrations. At these $\mathrm{pH}$ values, the majority of heavy metals precipitates in the form of hydroxides, e.g. pH values of complete precipitation (the residual concentration of metal is less than $10^{-5} \mathrm{~mol} \cdot \mathrm{1}^{-1}$ ) are 9.7 for $\mathrm{Fe}(\mathrm{OH})_{2}, 9.5$ for $\mathrm{Ni}(\mathrm{OH})_{2}, 6.8$ for $\mathrm{Cr}(\mathrm{OH})_{3}$ [3]. As for magnesium

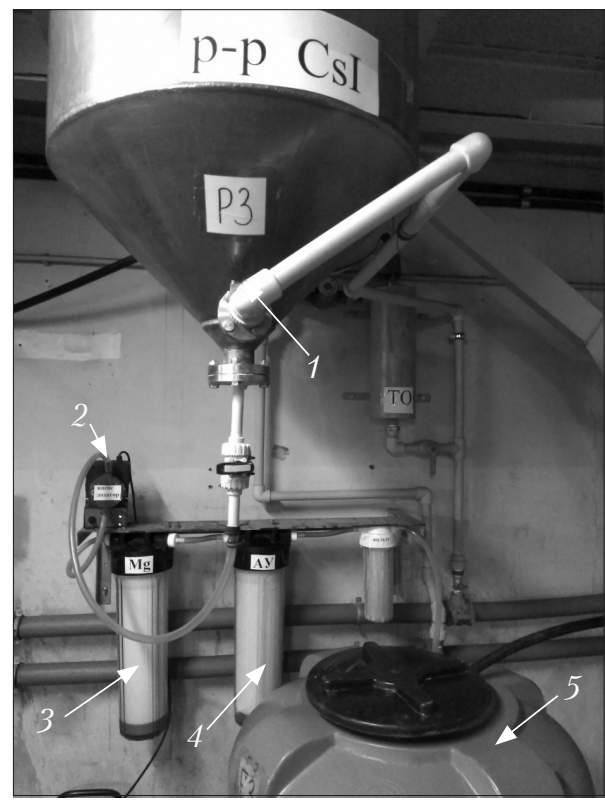

Fig. 2. The view of the experimental-industrial node of CsI purification by filtration through cartridge filters filled with magnesium and carbon: 1 - heat-exchange apparatus (titanium); 2 - metering pump; 3 - Mg-filled cartridge filter; 4 - activated carbon-filled cartridge filter; 5 - capacity for the filtered solution

admixture, the beginning of $\mathrm{Mg}(\mathrm{OH})_{2}$ precipitation from solutions of $10^{-2} \mathrm{~mol} \cdot \mathrm{l}^{-1}$ concentration is started at $\mathrm{pH}=10.4$, i.e., its content in the initial CsI solution is considerably higher.

Such admixtures as $\mathrm{Cu}$ and $\mathrm{Tl}$ form iodide complexes and due to this reason their precipitation under such $\mathrm{pH}$ values is incomplete. Ditto, thallium hydroxide and carbonate are good soluble in water. It is necessary to estimate the thermodynamic parameters of interactions between these heavy metal admixtures and metallic magnesium in iodide solutions. For this purpose, we performed the estimations based on the standard electrochemical potentials and stability constants of iodide complexes of copper and thallium. Namely, the standard electrochemical potentials, $\varphi_{\mathrm{Me}^{n+} / \mathrm{Me}^{0}}(\mathrm{~V})$ for the common reaction

$$
\mathrm{Me}^{n+}+n \overline{\mathrm{e}} \leftrightarrow \mathrm{Me}^{0},(\mathrm{Me}=\mathrm{Mg}, \mathrm{Cu}, \mathrm{Tl}),
$$

are as follows: -2.27 for $\mathrm{Mg}^{2+} / \mathrm{Mg},+0.531$ for $\mathrm{Cu}^{+} / \mathrm{Cu}$, and -0.357 for $\mathrm{Tl}^{+} / \mathrm{Tl}$ red-ox pairs. 
The calculations were made according to wellknown relations from physical chemistry.

The equilibrium constants for reactions of such a kind

$$
2 \mathrm{MeI}_{n}^{1-n}+\mathrm{Mg}^{0} \leftrightarrow 2 \mathrm{Me}^{0}+\mathrm{Mg}^{2+}+2 n \mathrm{I}^{-}, \log K_{\text {compl }}(8)
$$

for $\mathrm{Me}=\mathrm{Tl}(n=4)$ and $\mathrm{Me}=\mathrm{Cu}(n=2)$ were estimated since high concentration of iodide ion in the CsI initial solution favors the formation of complexes with maximal content of iodide ion $\left(\mathrm{TlI}_{4}^{3-}\right.$ and $\mathrm{CuI}_{2}^{-}$, respectively).

Reaction (8) presents itself a linear combination of reactions:

$$
\begin{gathered}
2 \mathrm{Me}^{+}+\mathrm{Mg}^{0} \leftrightarrow 2 \mathrm{Me}^{0}+\mathrm{Mg}^{2+}, \log K_{\varphi}= \\
=\frac{2 F}{2.3 R T}\left(\varphi_{\mathrm{Me}^{+} / \mathrm{Me}^{0}}^{0}-\varphi_{\mathrm{Me}^{2+} / \mathrm{Me}^{0}}^{0}\right)
\end{gathered}
$$

(where $F$ the Faraday's number $96485 \mathrm{C} \cdot \mathrm{mol}^{-1}$, $R$ the universal gas constant $8.314 \mathrm{~J} \cdot \mathrm{mol}^{-1} \cdot \mathrm{K}^{-1}, T$ the temperature, $\mathrm{K}$ ) and

$$
\mathrm{MeI}_{n}^{1-n} \leftrightarrow \mathrm{Me}^{+}+n \mathrm{I}^{-},-\log \beta,
$$

where $\beta$ is the stability constant of $\mathrm{TlI}_{4}^{3-}$ and $\mathrm{CuI}_{2}^{-}$ complexes, $-\log \beta$ values are equal to 1.6 and 8.85 , respectively. So, the final equation for equilibrium constants of (8) can be written as follows:

$$
\begin{gathered}
\log K_{\text {compl }}=\log K_{\varphi}-2 \log \beta= \\
=\frac{2 F}{2.3 R T}\left(\varphi_{\mathrm{Me}^{+} / \mathrm{Me}^{0}}^{0}-\varphi_{\mathrm{Me}^{2+} / \mathrm{Me}^{0}}^{0}\right)-2 \log \beta .
\end{gathered}
$$

From this equation $\log K_{\text {compl }}$ values can be estimated as $64.96(\mathrm{Me}=\mathrm{Tl})$ and $80.54(\mathrm{Me}=\mathrm{Cu})$ at $298 \mathrm{~K}$. Such high values of $\log K_{\text {compl }}$ mean that the process of reduction of $\mathrm{Tl}^{+}$and $\mathrm{Cu}^{+}$by the action of magnesium in iodide solutions is practically irreversible and should result in complete removal of the said heavy metal admixtures.

However, the beside of the thermodynamic predictions there exist kinetic limitations of the heterogeneous reaction (8) connected with the following schematic equation:

$$
w=k \cdot S_{\mathrm{Mg}} \cdot \mathrm{c}_{\mathrm{Me}^{+}}^{n},
$$

where $w$ is the rate of the heterogeneous reaction, $k$ the rate constant, $S_{\mathrm{Mg}}$ is the surface area of mag- nesium powder, $\mathrm{c}_{\mathrm{Me}^{+}}$the concentration of reagent in the solution and $n$ the kinetic order of the reaction. This relation means that the rate of the purification process is dependent, at first, on the surface of magnesium powder. Further, it is dependent on $\mathrm{Me}^{+}$concentration: the decrease of $c_{\mathrm{Me}^{+}}$due to the running of reaction (9) or formation of the complexes according to the reaction reverse to (10) should decrease the rate of the purification.

Therefore, a question arises: which conditions are necessary to provide quantitative removal of copper or thallium from the CsI initial solution? To answer this question we have performed the laboratory experiments which essence is described above and their results are presented in Table 1.

From Table 1 it can be seen that the use of both L1 and L2 routines gives the possibility to decrease the copper and thallium concentrations to values lower than the requirements of the technical conditions. As for the concentrations of other heavy metals even in the initial CsI solution it should be noted that there is no problem of special purification of CsI initial solution from such admixtures as $\mathrm{Fe}, \mathrm{Co}, \mathrm{Ni}$ and $\mathrm{Cr}$ since $\mathrm{pH}$ value of the technogenic solutions exceeds corresponding $\mathrm{pH}$ values of complete precipitation of the corresponding hydroxides. However, $\mathrm{Cu}$ and $\mathrm{Tl}$ remain in the solution at concentrations hindering the use of CsI obtained immediately from the technogenic solutions for the crystal growth of all the range of CsI-based scintillators. This takes place due to the formation of the strong above-considered iodide complexes in CsI solutions.

During the purification from the heavy metals the solution becomes more contaminated with respect to magnesium admixture, however, the degree of the contamination is not so high comparing with the initial CsI solution (by a factor of 1.5) and there is no trend of increasing degree of such contamination with the increase of a number of passing solution through the magnesium column (routine L2). This is caused by the fact 
that $\mathrm{Mg}(\mathrm{OH})_{2}$ precipitates in alkaline medium as a result of total process:

$2 \mathrm{Cs}_{\mathrm{n}-1} \mathrm{MeI}_{\mathrm{n}}+\mathrm{Mg}^{0}+2 \mathrm{CsOH}$ (alkaline medium!) $\leftrightarrow$ $\leftrightarrow 2 \mathrm{Me}^{0}+\mathrm{Mg}(\mathrm{OH})_{2} \downarrow+2 \mathrm{nCsI}$,

is slightly soluble in water [5] and this solubility restricts the contamination of the product (CsI) with magnesium.

Now let us consider the results of application of the developed laboratory routines.

It can be seen from Table 2 that the technological routine $\mathrm{T} 1$ became unsuccessful although the corresponding laboratory methods gave possibility to remove thallium down to concentration lower than the value required by the technical conditions [4]. The reason consists in the construction of the heat-exchange apparatus. As is seen from Fig. 1, the tube providing supply of air into the apparatus is placed over its bottom and metallic magnesium is collected just there and the stirring in this case is not so effective due to several reasons. The first of them consists in the reduction of the reaction surface since the particles of magnesium are collected together at the bottom. The second reason is connected with the passivation of magnesium due to the formation of $\mathrm{Mg}(\mathrm{OH})_{2}$ at its surface according to Eq. (13). Since magnesium is situated in zone of heat-exchange apparatus where the stirring of the solution is not so intensive this complicates the removal of magnesium hydroxide from the surface of the metal.

On the contrary, the routine $\mathrm{T} 2$ including the filtering of the solution heated to $60-70{ }^{\circ} \mathrm{C}$ permits to decrease thallium concentration to the level less than $5 \cdot 10^{-5}$ mas. \% that makes the pro-

Table 1. The Results of Analysis of CsI Obtained from Solutions after Treatment by Metallic Magnesium under the Laboratory Conditions

\begin{tabular}{|c|c|c|c|c|c|}
\hline \multirow{2}{*}{ Sample, method of treatment } & \multirow{2}{*}{$\begin{array}{l}\mathrm{pH} \text { of the initial } \\
\text { solution }\end{array}$} & \multicolumn{4}{|c|}{ Content of element in dry CsI salt, mas.\% } \\
\hline & & $\mathrm{Mg}$ & $\mathrm{Cu}$ & $\mathrm{Fe}$ & $\mathrm{Tl}$ \\
\hline The initial CsI solution & $10.2-10.6$ & $1.5 \cdot 10^{-2}$ & $2 \cdot 10^{-4}$ & $<3 \cdot 10^{-5}$ & $4.2 \cdot 10^{-3}$ \\
\hline L1 & 10.2 & $2.3 \cdot 10^{-2}$ & $<5 \cdot 10^{-6}$ & $<3 \cdot 10^{-5}$ & $<1 \cdot 10^{-5}$ \\
\hline $\mathrm{L} 2,1^{\text {st }}$ passing & 10.3 & $2.1 \cdot 10^{-2}$ & $<5 \cdot 10^{-6}$ & $<3 \cdot 10^{-5}$ & $4.5 \cdot 10^{-4}$ \\
\hline $\mathrm{L} 2,2^{\text {nd }}$ passing & 10.1 & $2.3 \cdot 10^{-2}$ & $<5 \cdot 10^{-6}$ & $<3 \cdot 10^{-5}$ & $8.0 \cdot 10^{-5}$ \\
\hline $\mathrm{L} 2,3^{\text {rd }}$ passing & 10.3 & $2.4 \cdot 10^{-2}$ & $<5 \cdot 10^{-6}$ & $<3 \cdot 10^{-5}$ & $6.0 \cdot 10^{-5}$ \\
\hline $\mathrm{L} 2,4^{\text {th }}$ passing & 10.2 & $2.0 \cdot 10^{-2}$ & $<5 \cdot 10^{-6}$ & $<3 \cdot 10^{-5}$ & $3.5 \cdot 10^{-5}$ \\
\hline $\begin{array}{l}\text { Technical conditions (TU U } \\
24.13 .31331736-002-2004)[4]\end{array}$ & & $5 \cdot 10^{-5}$ & $5 \cdot 10^{-6}$ & $3 \cdot 10^{-5}$ & $5.0 \cdot 10^{-5}$ \\
\hline
\end{tabular}

Table 2. The Results of Analysis of CsI Obtained from Solutions after Treatment by Metallic Magnesium According to Technological Routines T1 and T2

\begin{tabular}{|l|c|c|c|c|c|}
\hline \multirow{2}{*}{ Sample, method of treatment } & \multirow{2}{*}{$\begin{array}{c}\mathrm{pH} \text { of the initial } \\
\text { solution }\end{array}$} & \multicolumn{3}{|c|}{ Content of element in dry CsI salt, mas.\% } \\
\cline { 3 - 6 } & & $\mathrm{Mg}$ & $\mathrm{Cu}$ & $\mathrm{Fe}$ & $\mathrm{Tl}$ \\
\hline The initial CsI solution & $10.2-10.6$ & $1.5 \cdot 10^{-2}$ & $2 \cdot 10^{-4}$ & $<3 \cdot 10^{-5}$ & $4.2 \cdot 10^{-3}$ \\
T1, $1^{\text {st }}$ sample, dry salt & 6.1 & $3 \cdot 10^{-5}$ & $<5 \cdot 10^{-6}$ & $<3 \cdot 10^{-5}$ & $2.6 \cdot 10^{-3}$ \\
$\mathrm{~T}_{1} 2^{\text {nd }}$ sample, dry salt & 6.3 & $6 \cdot 10^{-5}$ & $<5 \cdot 10^{-6}$ & $<3 \cdot 10^{-5}$ & $2.9 \cdot 10^{-3}$ \\
T2, $1^{\text {st }}$ sample, dry salt & 6.2 & $5 \cdot 10^{-5}$ & $<5 \cdot 10^{-6}$ & $<3 \cdot 10^{-5}$ & $5 \cdot 10^{-5}$ \\
T2, $2^{\text {nd }}$ sample, dry salt & 6.3 & $6 \cdot 10^{-5}$ & $<5 \cdot 10^{-6}$ & $<3 \cdot 10^{-5}$ & $4 \cdot 10^{-5}$ \\
Technical conditions (TU U & & $5 \cdot 10^{-5}$ & $5 \cdot 10^{-6}$ & $3 \cdot 10^{-5}$ & $5.0 \cdot 10^{-5}$ \\
24.13.31331736-002-2004) [4] & $<6.5$ & & & &
\end{tabular}




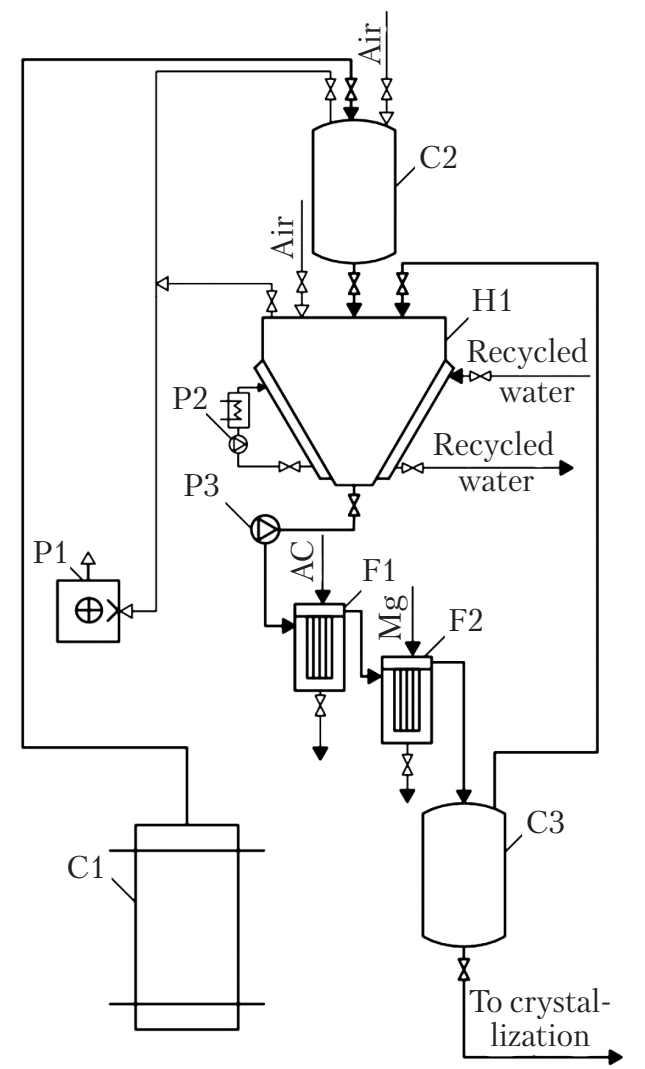

Fig. 3. The technological scheme of experimental-industrial area of purification of the CsI technogenic solution from heavy metal admixtures: $\mathrm{C} 1$ - transport capacity; C2 measure capacity; C3 - collecting capacity; P1 - watercycle vacuum pump; P2 - circulation pump; P3 - measuring pump; H1 - heat exchange apparatus; F1 - activated carbon-filled cartridge filter; AC - activated carbon; F2 Mg-filled cartridge filter

duct (cesium iodide) available for the growth of activated crystals on the basis of CsI.

The technological scheme of experimental-industrial node of purification of the CsI technogenic solution from heavy metal admixtures is presented in Fig. 3.

According to the developed technology the technogenic solution of CsI single crystals wastes is supplied in transport capacities (C1) with a volume of $1000 \mathrm{l}$ each.

Before starting the purification process, it is necessary to check the readiness of the facility of CsI solutions purification from heavy-metals admixtures:
- to check the impermeability of apparatus, filters, fittings etc.;

- to estimate the performance of electrical equipment: pumps and other devices;

- to turn off all the taps on vacuum and transport mains.

The purification of CsI solution from the heavy-metals admixtures is provided by the treatment with an active metal - magnesium. Heavy metal cations are reduced during the passing of CsI solution through the layer of magnesium according to Eq. (8) and magnesium cation is bonded into insoluble hydroxide in the alkaline environment:

$$
\mathrm{Mg}^{2+}+2 \mathrm{OH}^{-} \rightarrow \mathrm{Mg}(\mathrm{OH})_{2} \downarrow
$$

To provide this interaction, the cartridge filter F1 is filled with $4 \mathrm{~kg}$ of magnesium preliminary purified from the metal dust.

An activated carbon is used to provide the purification of CsI wastes' solution from the suspended particles and precipitates formed during its heating, non-dissociated substances and from organic admixtures as well. To provide such a treatment the cartridge filter F2 is filled with 4 $\mathrm{kg}$ of activated carbon previously washed by water to separate the coal dust.

The frequency of cartridge replacement for both filters is 1 time per 4 operations.

The measure capacity $\mathrm{C} 2$ is used to provide the necessary volume of CsI solution for the technological process. The routine of CsI solution transport from $\mathrm{C} 1$ to $\mathrm{C} 2$ is following.

The suction hose from $\mathrm{C} 2$ is placed into $\mathrm{C} 1$. Then the tap on the suction hose is turned off and the vacuum pump P1 and the tap on vacuum main between P1 and C2 are turned on. When the necessary level of the pressure is acquired the tap on suction hose is turned on and the solution is transported to the $\mathrm{C} 2$. The volume of solution is controlled by the measuring line on the apparatus wall.

When 1861 of the solution are transported into capacity $\mathrm{C} 2$ the taps on suction hose and vacuum main are turned off and the apparatus is re-pressured with an atmospheric air. 
After that the tap at the bottom of $\mathrm{C} 2$ is turned on and all the solution is transported into the heat exchange apparatus $\mathrm{H} 1$ by the transport main.

The heating of the solution in apparatus $\mathrm{H} 1$ is provided by heating and recycling of water in the apparatus shirt. The heating process goes automatically after inserting the necessary value of the temperature on the control panel. The CsI solution is maintained in $\mathrm{H} 1$ under the temperature of $60{ }^{\circ} \mathrm{C}$ for $1 \mathrm{~h}$.

Then the tap at the bottom of $\mathrm{H} 1$ is turned on and solution is transported by a measuring pump P3 to the filter F1 with a rate of $7-8$ liters per hour. After that solution drifts to the filter F2 and into the collecting capacity C3.

To provide the necessary level of purification the CsI solution needs to be passed through the cartridge filters 5 times. For this purpose, the suction hose from H1 is placed into C3. Then the tap on the suction hose is turned off and the vacuum pump P1 and the tap on vacuum main between P1 and H1 are turned on. When the necessary level of the pressure is acquired the tap on suction hose is turned on and the solution is transported to the H1. After that the technological process goes as it was described above.
It should be noted that the similar approach can be applied for the removal of other heavy metals from waste solutions, which cannot be removed by other methods. Such a treatment leads to substitution of toxic heavy metal ions with $\mathrm{Mg}^{2+}$ which maximum allowable concentration in, e.g., domestic water is ca. $80 \mathrm{mg}$ per liter.

The main result of this research is the development of technology of purification of cesium iodide technogenic solutions from admixtures of heavy metals including thallium. To provide the purification we proposed the treatment of wastes of Cs-based crystal by the metallic magnesium.

Two possible ways of the solution have been studied under laboratory conditions and led to good results. An attempts to level these routines to existing experimental equipment working in ISMA showed that only one of them met the constructional features of the equipment. The technology based on this method was implemented in the acting manufacturing.

The financial support of National Academy of Sciences of Ukraine (direction No 411 from July 25, 2018, project No 18) is gratefully acknowledged.

\section{REFERENCES}

1. Efimov, A. I., Belorukova, L. P., Vasil'kova, I. V., Chechev, V. P. (1983). Properties of inorganic compounds. Leningrad: Khimiya [In Russian].

2. Cherginets, V. L., Ponomarenko, T. V., Rebrova, T. P., Varich, A. G., Rebrov, A. L., Datsko, Yu. N. (2018). On the features of crystallization methods used for the purification of aqueous solutions of cesium iodide. Functional Materials, 25(3), 594-600.

3. Goronovskiy, I. T., Nazarenko, Yu. P., Nekryach, E. F. (1987). Short handbook on chemistry. Kiev: Naukova dumka [In Russian].

4. Cesium iodide of extra pure quality for single crystals / Technical conditions TU U24.13.31331736 - 002 - 2004, 2004.

5. Ryznar, J. W., Green, J., Winterstein, M. G. (1946). Determination of the pH of saturation of magnesium hydroxide. Ind. Eng. Chem., 38(10), 1057-1061.

Received 15.03.19

Revised 22.03.19

Accepted 22.03.19 
Б.В. Гриньов, В.Л. Чергинещь, Т.П. Реброва,

Т.В. Пономаренко, А.Г. Варич, О.Л. Ребров

Інститут сцинтиляційних матеріалів Національної академії наук України, просп. Науки, 60, Харків, 61072, Україна, +380 57341 0150, +380 57340 4474, v_cherginets@ukr.net

\section{ТЕХНОЛОГІЯ ГЛИБОКОГО ОЧИЩЕННЯ ЗАЛИШКІВ ВИРОБНИЦТВА МОНОКРИСТАЛІВ ЙОДИДУ ЦЕЗІЮ ВІД ВАЖКИХ МЕТАЛІВ}

Вступ. Виробництво активованих сцинтиляційних монокристалів на основі йодиду цезію супроводжується накопиченням залишків вирощування і обробки кристалів. Їх ретельне очищення від домішок важких металів є головною умовою подальшого використання йодиду цезію при одержанні різних типів монокристалів активованого CsI.

Проблематика. Основною домішкою у залишках виробництва монокристалів на основі йодиду цезію $є$ талій, оскільки TlI використовується як активатор при вирощуванні монокристалів CsI:Tl. Талій - важкий метал, домішку якого найбільш складно видалити із зазначених залишків, тому розробка ефективної технології очищення техногенних розчинів CsI від домішок важких металів є актуальною.

Мета. Розробка технології очищення залишків виробництва монокристалів на основі CsI від домішок важких металів до рівня чистоти, зазначеної у вимогах національних нормативних документів для йодиду цезію особливої чистоти.

Матеріали й методи. Як матеріал було використано розчини залишків виробництва монокристалів на основі CsI, активне вугілля, магній, гідроксид барію, карбонат цезію. Методи: обробка суміші нагрітого розчину залишків і очищувача при перемішуванні; багаторазове фільтрування нагрітого розчину залишків через патронні фільтри, заповнені очищувачами.

Результати. Метод обробки техногенного розчину йодиду цезію магнієм при нагріванні та перемішуванні є ефективним в лабораторних випробуваннях, але його застосування у виробничих умовах не дало позитивного результату. У промислових умовах ефективним виявився метод багаторазового пропускання нагрітого розчину CsI через патронні фільтри, заповнені очищувачами. Використання зазначеного методу дозволило одержати особливо чистий продукт - CsI, який за якістю відповідає вимогам ТУ У 24.13.31331736-002-2004.

Висновки. Розроблено нову технологію очищення залишків виробництва монокристалів на основі йодиду цезію від домішок важких металів, зокрема й талію.

Ключові слова: йодид цезію, техногенний розчин, очищення, важкі метали, магній. 